\title{
Experimental evidence for light Ba isotopes favouring aqueous fluids over silicate melts
}

\author{
H. Guo ${ }^{1,2,3^{*}}$, W.-Y. $\mathrm{Li}^{4,5^{*}}$, X. Nan ${ }^{4}$, F. Huang ${ }^{4,5}$
}

Abstract

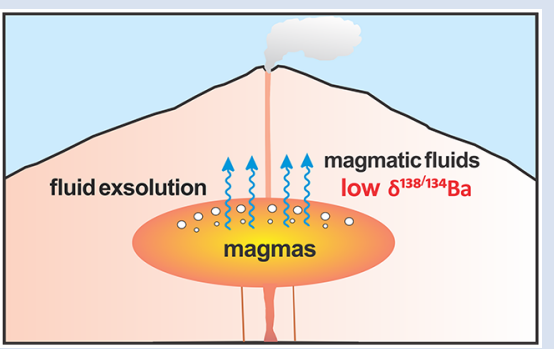

Barium (Ba) is a fluid mobile element and enriched in the Earth's crust, which has potential implications for constraining fluid activities during magmatichydrothermal processes. However, the behaviour of Ba and its isotopes during fluid exsolution from magma is poorly known. Here we present an experimental study on determining the $\mathrm{Ba}$ partition coefficient ( $\mathrm{D}_{\text {FLUID-MELT }}$ ) and equilibrium isotope fractionation factor $\left(\alpha^{138 / 134} \mathrm{Ba}_{\text {FLUID-MELT }}\right)$ between aqueous fluids and silicate melts with different chemical compositions at $700-900{ }^{\circ} \mathrm{C}$ and $200 \mathrm{MPa}$ using cold seal pressure vessels. The results show that $\mathrm{D}_{\text {FLUID-MELT }}$ ranges from 0.02 to 0.20 , while $\Delta \Delta^{138 / 134} \mathrm{Ba}_{\text {FLUID-MELT }}[\approx 1000 \times(\alpha-1)]$ ranges from $-0.62 \%$ to $-0.14 \%$. Both $\mathrm{D}_{\text {FLUID-MELT }}$ and $\Delta^{138 / 134} \mathrm{Ba}_{\text {FLUID-MELT }}$ positively correlate with temperature, the salinity of fluid and alumina saturation index (ASI) of melt. The finding that light Ba isotopes are enriched in aqueous fluids relative to silicate melts suggests that the fluid exsolution process cannot explain the observed light Ba isotopic compositions of some granites. Moreover, the experimentally determined $\alpha^{138 / 134} \mathrm{Ba}_{\text {FLUID-MELT }}$ is useful for tracing fluid activities in felsic intrusion-related hydrothermal deposits and in seafloor hydrothermal systems.

Received 11 July 2020 | Accepted 5 October 2020 | Published 9 November 2020

\section{Introduction}

As an alkaline earth metal, Ba is a large ion lithophile element (LILE) and fluid mobile element. It has seven stable isotopes, i.e. ${ }^{130} \mathrm{Ba}(0.11 \%),{ }^{132} \mathrm{Ba}(0.10 \%),{ }^{134} \mathrm{Ba}(2.42 \%),{ }^{135} \mathrm{Ba}(6.59 \%)$, ${ }^{136} \mathrm{Ba}(7.85 \%),{ }^{137} \mathrm{Ba}(11.23 \%)$ and ${ }^{138} \mathrm{Ba}(71.70 \%)$ (Eugster et al., 1969). Due to the high incompatibility of Ba during mantle melting $\left(D_{\text {SOLID-MELT }}=0.00012\right.$; Workman and Hart, 2005), it is strongly enriched in the continental crust relative to the mantle. The average concentration of $\mathrm{Ba}$ of the upper continental crust (628 ppm; Rudnick and Gao, 2003) is remarkably higher than that of the average mantle ( 7 ppm; Sun and McDonough, 1989). Recently, significant $\mathrm{Ba}$ isotopic variations $\left(\delta^{138 / 134} \mathrm{Ba}=-0.62 \%\right.$ o to $+0.15 \%$; Nan et al., 2018) have been observed in granites (Fig. S-1), which may result from assimilation of crustal materials, fractional crystallisation, and/or fluid exsolution. Barium is also strongly enriched in seafloor hydrothermal fluids (1.6 to $100 \mu \mathrm{mol} / \mathrm{kg}$ ) compared to seawater $(0.14 \mu \mathrm{mol} / \mathrm{kg}$; Tivey, 2007). The input of Ba from seafloor hydrothermal activities has been suggested to affect the Ba isotopic composition of the deep ocean (Hsieh and Henderson, 2017). Therefore, Ba isotopes may provide a potential tool for constraining differentiation of granitic magma and the oceanic budget of Ba.

Fluid exsolution from melts is common in igneous processes and plays an important role in the formation of magmatichydrothermal ore deposits (e.g., Hedenquist and Lowenstern,
1994). Significant stable isotope fractionation of $\mathrm{Zn}, \mathrm{B}$ and $\mathrm{Cu}$ isotopes during fluid exsolution has been demonstrated in previous studies, with corresponding geological applications (e.g., Telus et al., 2012; Maner and London, 2018; Guo et al., 2020). Barium isotopes may also be useful in tracing fluid activities, and the knowledge about the fractionation behaviour of $\mathrm{Ba}$ isotopes during magmatic-hydrothermal processes is a necessary prerequisite. However, there is still no study on the key parameter of the equilibrium Ba isotope fractionation factor between aqueous fluids and silicate melts ( $\alpha^{138 / 134} \mathrm{Ba}_{\text {FLUID-MELT }}$ ).

Here, for the first time, we experimentally measured $\alpha^{138 / 134} \mathrm{Ba}_{\text {FLUID-MELT }}$ between aqueous fluids and silicate melts with different chemical compositions at $700-900{ }^{\circ} \mathrm{C}$ and $200 \mathrm{MPa}$. The results show that, in equilibrium, the fluids are isotopically lighter than the melts. This finding promises important applications of $\mathrm{Ba}$ isotopes in tracing hydrothermal fluid activities during magma differentiation, magmatic-hydrothermal mineralisation, and seafloor hydrothermal activity.

\section{Methods}

Phase equilibrium experiments within cold seal pressure vessels have been widely used to determine the partitioning coefficients of elements (e.g., Borchert et al., 2010). Recently, this method has

1. Bayerisches Geoinstitut, Universität Bayreuth, 95440 Bayreuth, Germany

2. Department of Earth and Planetary Sciences, McGill University, Montreal H3A 0E8, Canada

3. ISTO, UMR 7327 CNRS-Université d'Orléans-BRGM, 45071 Orléans, France

4. CAS Key Laboratory of Crust-Mantle Materials and Environments, School of Earth and Space Sciences, University of Science and Technology of China, Hefei, Anhui 230026, China

5. CAS Center for Excellence in Comparative Planetology, University of Science and Technology of China, Hefei, Anhui 230026, China

* Corresponding authors (email: haihao.guo@cnrs-orleans.fr; wyli@ustc.edu.cn) 
been successfully applied to obtain the equilibrium $\mathrm{Cu}$ isotope fractionation factors between aqueous fluids and silicate melts (Guo et al., 2020). In this study, similar experiments were performed at $700-900{ }^{\circ} \mathrm{C}$ and $200 \mathrm{MPa}$ in rapid quenched cold seal pressure vessels (the capsule design is shown in Fig. S-2a). Besides temperature, chemical compositions of the fluid and melt will also affect the equilibrium $\mathrm{Ba}$ isotope fractionation factors, so a series of Ba-doped haplogranitic glasses from peralkaline to peraluminous (with ASI ranging from 0.8 to 1.2), and $0.5-1.5 \mathrm{~mol} / \mathrm{L} \mathrm{NaCl}+\mathrm{KCl}$ ( $\mathrm{Na}: \mathrm{K}=1: 1$ in moles) bearing fluids were used as starting materials. Approximately 1:1 fluid and glass in mass were loaded into gold capsules, and were subsequently equilibrated in the cold seal pressure vessels for 1040 days. After rapid quenching the experiments, the fluid and glass (quenched melt) phases were carefully and completely separated, and then transferred into solutions respectively. No other mineral phases were observed in the quenched glasses (Fig. S-2b). Afterwards, the Ba concentrations and Ba isotopic compositions of the solutions prepared from the run products were measured by ICP-MS and MC-ICP-MS, respectively. Additional details about the experimental and analytical methods are given in the Supplementary Information.

\section{Results and Discussion}

The experimental conditions and results are listed in Table 1. The attainment of equilibrium Ba partitioning and isotope fractionation between fluids and melts was evidenced by the time series experiments. Experiments with the duration of 10, 20 and 40 days show similar results for both $D_{\text {FLUID-MELT }}$ and $\Delta^{138 / 134} \mathrm{Ba}_{\text {FLUID-MELT }}$ (Fig. S-3). In addition, our experimental durations are longer than or comparable to those of previous studies that have achieved equilibrium partitioning of $\mathrm{Ba}$ between fluids and melts (e.g., 5-12 days at $750-950{ }^{\circ} \mathrm{C}$ and $200 \mathrm{MPa}$; Borchert et al., 2010). Therefore, the experimental results summarised in Table 1 represent the equilibrium values.
Figure 1 shows that $\mathrm{D}_{\text {FLUID-MELT }}$ ranges from 0.02 to 0.20 , while $\Delta^{138 / 134} \mathrm{Ba}_{\text {FLUID-MELT }}$ ranges from $-0.62 \%$ to $-0.14 \%$, both of which change with the temperature and display good positive correlations with salinity of the fluid and ASI of the melt. Specifically, at the fixed melt ASI $=1.0$ and fluid salinity of $1 \mathrm{~mol} / \mathrm{L}(\mathrm{Na}, \mathrm{K}) \mathrm{Cl}, \mathrm{D}_{\text {FLUID-MELT }}$ increases from 0.06 to 0.10 , and $\Delta^{138 / 134} \mathrm{Ba}_{\text {FLUID-MELT }}$ increases from $-0.62 \pm 0.07 \%$ to $-0.20 \pm 0.07 \%$ with temperature increasing from 700 to $900{ }^{\circ} \mathrm{C}$ (Table 1, Fig. 1a,b). Both fluid salinity and melt ASI are important factors that affect $D_{\text {FLUID-MELT }}$ and $\Delta^{138 / 134} \mathrm{Ba}_{\text {FLUID-MELT. For }}$ example, at $800{ }^{\circ} \mathrm{C}$ and the melt ASI of 1.0, increasing the $(\mathrm{Na}, \mathrm{K}) \mathrm{Cl}$ concentration from 0.5 to $1.5 \mathrm{~mol} / \mathrm{L}$ in the starting fluids enhances $\mathrm{D}_{\text {FLUID-MELT }}$ from 0.04 to 0.20 , and $\Delta^{138 / 134} \mathrm{Ba}$ FLUID-MELT from $-0.31 \pm 0.07 \%$ o to $-0.14 \pm 0.07 \%$, respectively (Table 1 , Fig. 1c,d). Similarly, at $800{ }^{\circ} \mathrm{C}$ and the fluid with $1 \mathrm{~mol} / \mathrm{L}$ $(\mathrm{Na}, \mathrm{K}) \mathrm{Cl}$, increasing the ASI from 0.8 to 1.2 in the starting haplogranitic glasses enhances $D_{\text {FLUID-MELT }}$ from 0.02 to 0.17 , and $\Delta^{138 / 134} \mathrm{Ba}_{\text {FLUID-MELT }}$ from $-0.44 \pm 0.07 \%$ o to $-0.16 \pm 0.07 \%$, respectively (Table 1, Fig. 1e,f).

The correlations of $\mathrm{D}_{\text {FLUID-MELT }}$ and $\Delta^{138 / 134} \mathrm{Ba}_{\text {FLUID-MELT }}$ with temperature, fluid salinity and melt ASI can be expressed by numerical regression equations. Since both $D_{\text {FLUID-MELT }}$ and $\Delta^{138 / 134} \mathrm{Ba}_{\text {FLUID-MELT }}$ have a linear function with fluid salinity and melt ASI (Fig. 1c-f), as well as $\mathrm{D}_{\text {FLUID-MELT }}$ is generally expressed as a function of $1 / \mathrm{T}$ while $\Delta^{138 / 134} \mathrm{Ba}_{\text {FLUID-MELT }}$ as a function of $1 / \mathrm{T}$ and $1 / \mathrm{T}^{2}$, the regression equations can be described as

$$
\begin{aligned}
\mathrm{D}_{\text {FLUID-MELT }}=-0.177 \pm 0.159 & -(276.0 \pm 151.5) * 1 / \mathrm{T} \\
+(0.156 \pm 0 & .027) \mathrm{Cl}+(0.373 \pm 0.067) \mathrm{ASI} \\
\Delta^{138 / 134} \mathrm{Ba}_{\mathrm{FLUID}-\mathrm{MELT}}(\% \mathrm{o})= & -14.96 \pm 3.32 \\
& -(18221013 \pm 4641078) * 1 / \mathrm{T}^{2} \\
& +(31828 \pm 8761) * 1 / \mathrm{T} \\
& +(0.167 \pm 0.062) \mathrm{Cl} \\
& +(0.699 \pm 0.155) \mathrm{ASI}
\end{aligned}
$$

\begin{tabular}{|c|c|c|c|c|c|c|c|c|c|c|c|c|c|c|}
\hline \multirow{2}{*}{$\begin{array}{l}\text { Run } \\
\text { No. }\end{array}$} & \multirow[b]{2}{*}{$\mathrm{T}\left({ }^{\circ} \mathrm{C}\right)$} & \multirow{2}{*}{$\begin{array}{c}\mathrm{P} \\
\text { (kbar) }\end{array}$} & \multirow{2}{*}{$\begin{array}{l}\text { Duration } \\
\text { (days) }\end{array}$} & \multirow{2}{*}{$\begin{array}{l}\text { Starting } \\
\text { melt ASI }\end{array}$} & \multirow{2}{*}{$\begin{array}{l}\text { Starting } \\
\text { fluid }\end{array}$} & \multicolumn{3}{|c|}{ Melt product } & \multicolumn{3}{|c|}{ Fluid product } & \multirow[b]{2}{*}{$\mathrm{D}_{\mathrm{Ba}^{a}}{ }^{\mathrm{a}}$} & \multirow{2}{*}{$\begin{array}{c}\Delta^{138 / 134} \\
\text { Ba }_{\text {FLUID-MELT }}^{\text {b }}\end{array}$} & \multirow[b]{2}{*}{2 s.d. $^{\text {b }}$} \\
\hline & & & & & & $\begin{array}{c}\mathrm{Ba} \\
(\mathrm{ppm})\end{array}$ & $\begin{array}{c}\delta_{(\% 0}^{138 / 134} \mathrm{Ba} \\
\end{array}$ & 2 s.d. & $\begin{array}{c}\mathrm{Ba} \\
(\mathrm{ppm})\end{array}$ & $\begin{array}{c}\delta_{(\% 0}^{138 / 134} \mathrm{Ba} \\
\end{array}$ & 2 s.d. & & & \\
\hline Ba05 & 800 & 2 & 10 & 1.0 & $\begin{array}{c}1 \mathrm{~m} \\
(\mathrm{Na}, \mathrm{K}) \mathrm{Cl}\end{array}$ & 1289 & 0.03 & 0.05 & 115 & -0.18 & 0.05 & 0.09 & -0.21 & 0.07 \\
\hline Ba15 & 800 & 2 & 20 & 1.0 & $\begin{array}{c}1 \mathrm{~m} \\
(\mathrm{Na}, \mathrm{K}) \mathrm{Cl}\end{array}$ & 1140 & 0.04 & 0.05 & 112 & -0.20 & 0.04 & 0.10 & -0.24 & 0.06 \\
\hline Ba14 & 800 & 2 & 40 & 1.0 & $\begin{array}{c}1 \mathrm{~m} \\
(\mathrm{Na}, \mathrm{K}) \mathrm{Cl}\end{array}$ & 1145 & 0.07 & 0.03 & 89 & -0.18 & 0.01 & 0.08 & -0.25 & 0.03 \\
\hline $\mathrm{Ba} 06$ & 900 & 2 & 10 & 1.0 & $\begin{array}{c}1 \mathrm{~m} \\
(\mathrm{Na}, \mathrm{K}) \mathrm{Cl}\end{array}$ & 1186 & 0.08 & 0.05 & 121 & -0.12 & 0.05 & 0.10 & -0.20 & 0.07 \\
\hline $\mathrm{Ba} 07$ & 700 & 2 & 20 & 1.0 & $\begin{array}{c}1 \mathrm{~m} \\
(\mathrm{Na}, \mathrm{K}) \mathrm{Cl}\end{array}$ & 1227 & 0.10 & 0.05 & 69 & -0.52 & 0.05 & 0.06 & -0.62 & 0.07 \\
\hline Ba09 & 800 & 2 & 10 & 1.0 & $\begin{array}{c}0.5 \mathrm{~m} \\
(\mathrm{Na}, \mathrm{K}) \mathrm{Cl}\end{array}$ & 1427 & 0.07 & 0.05 & 57 & -0.24 & 0.05 & 0.04 & -0.31 & 0.07 \\
\hline Ba10 & 800 & 2 & 10 & 1.0 & $\begin{array}{c}1.5 \mathrm{~m} \\
(\mathrm{Na}, \mathrm{K}) \mathrm{Cl}\end{array}$ & 1291 & 0.05 & 0.05 & 253 & -0.09 & 0.05 & 0.20 & -0.14 & 0.07 \\
\hline Ba11 & 800 & 2 & 10 & 0.8 & $\begin{array}{c}1 \mathrm{~m} \\
(\mathrm{Na}, \mathrm{K}) \mathrm{Cl}\end{array}$ & 1253 & 0.06 & 0.05 & 23 & -0.38 & 0.05 & 0.02 & -0.44 & 0.07 \\
\hline Ba12 & 800 & 2 & 10 & 1.2 & $\begin{array}{c}1 \mathrm{~m} \\
(\mathrm{Na}, \mathrm{K}) \mathrm{Cl}\end{array}$ & 702 & 0.07 & 0.05 & 118 & -0.09 & 0.05 & 0.17 & -0.16 & 0.07 \\
\hline
\end{tabular}$$
\text { Eq. } 1
$$

Eq. 2

Table 1 Summary of experimental conditions and results.

${ }^{a} \mathrm{D}_{\mathrm{Ba}}$ is the partitioning coefficient between fluid and melt, which is calculated from the concentration of Ba in the fluid product and that in the melt product. ${ }^{\mathrm{b}} \Delta^{138 / 134} \mathrm{Ba}_{\text {FLUID-MELT }}=\delta^{138 / 134} \mathrm{Ba}_{\text {Fluid }}-\delta^{138 / 134} \mathrm{Ba}_{\text {Melt }}$ and the uncertainties $(2$ s.d.) are calculated by error propagation. 

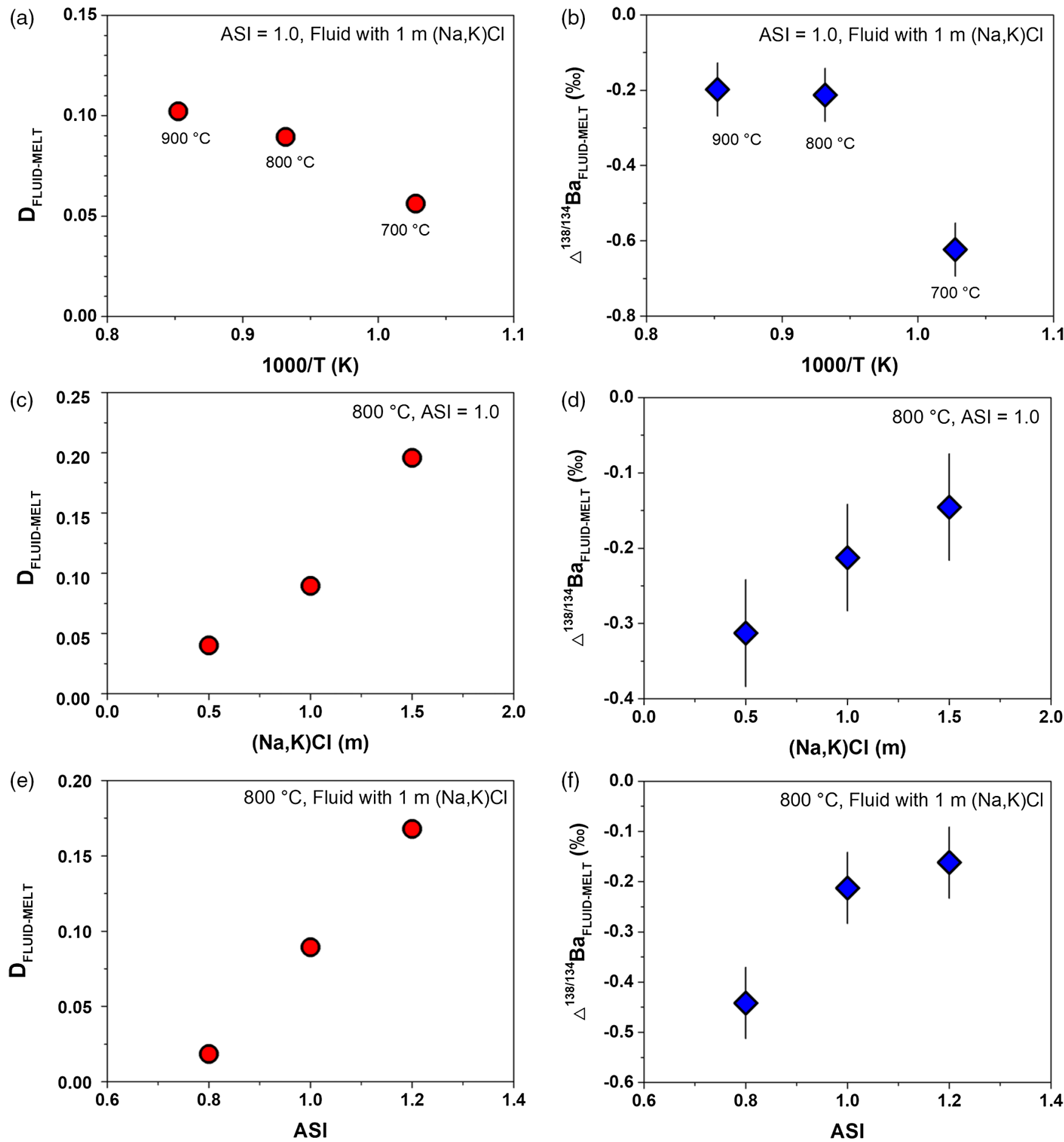

Figure 1 Partitioning coefficient ( $D_{\text {FLUID-MELT }}$ ) and equilibrium isotope fractionation ( $\triangle{ }^{138 / 134} \mathrm{Ba}_{\text {FLUID-MELT }}$ ) of $\mathrm{Ba}$ between aqueous fluid and silicate melt as a function of temperature from 700 to $900^{\circ} \mathrm{C}(\mathbf{a}, \mathbf{b})$, salinity of the fluid $(\mathbf{c}, \mathbf{d})$, and ASI of the melt $(\mathbf{e}, \mathbf{f})$. Error bars in $\mathbf{b}, \mathbf{d}, \mathbf{a n d} \mathbf{f}$ represent 2 s.d. uncertainties (see Table 1).

where $\mathrm{T}$ is temperature in Kelvin and $\mathrm{Cl}$ is the $(\mathrm{Na}, \mathrm{K}) \mathrm{Cl}$ molarity concentration of fluid. The $\mathrm{D}_{\text {FLUID-MELT }}$ and $\Delta^{138 / 134} \mathrm{Ba}_{\text {FLUID-MELT }}$ values predicted by the Eqs. 1 and 2 are consistent with the experimentally measured data (Fig. S-4), indicating that these two equations can provide reliable estimations.

Our work demonstrates for the first time that, in equilibrium conditions, aqueous fluids are enriched in light $\mathrm{Ba}$ isotopes compared to the coexisting silicate melts. This observation provides direct constraints on the behaviour of $\mathrm{Ba}$ isotopes during fluid exsolution from silicate melts. Based on the $\mathrm{D}_{\text {FLUID-MELT }}$ and $\Delta^{138 / 134} \mathrm{Ba}_{\text {FLUID-MELT }}$ obtained here (Eqs. 1 and 2), we use the Rayleigh fractionation model to simulate the Ba isotopic compositions of the exsolved aqueous fluid and residual silicate melt in natural conditions (modelling details are available in the Supplementary Information).

Figure 2 shows that the modelled $\delta^{138 / 134} \mathrm{Ba}$ of the residual melt and exsolved fluid are related to the fluid fraction, temperature, ASI of the melt, and salinity of the fluid. The most obvious 

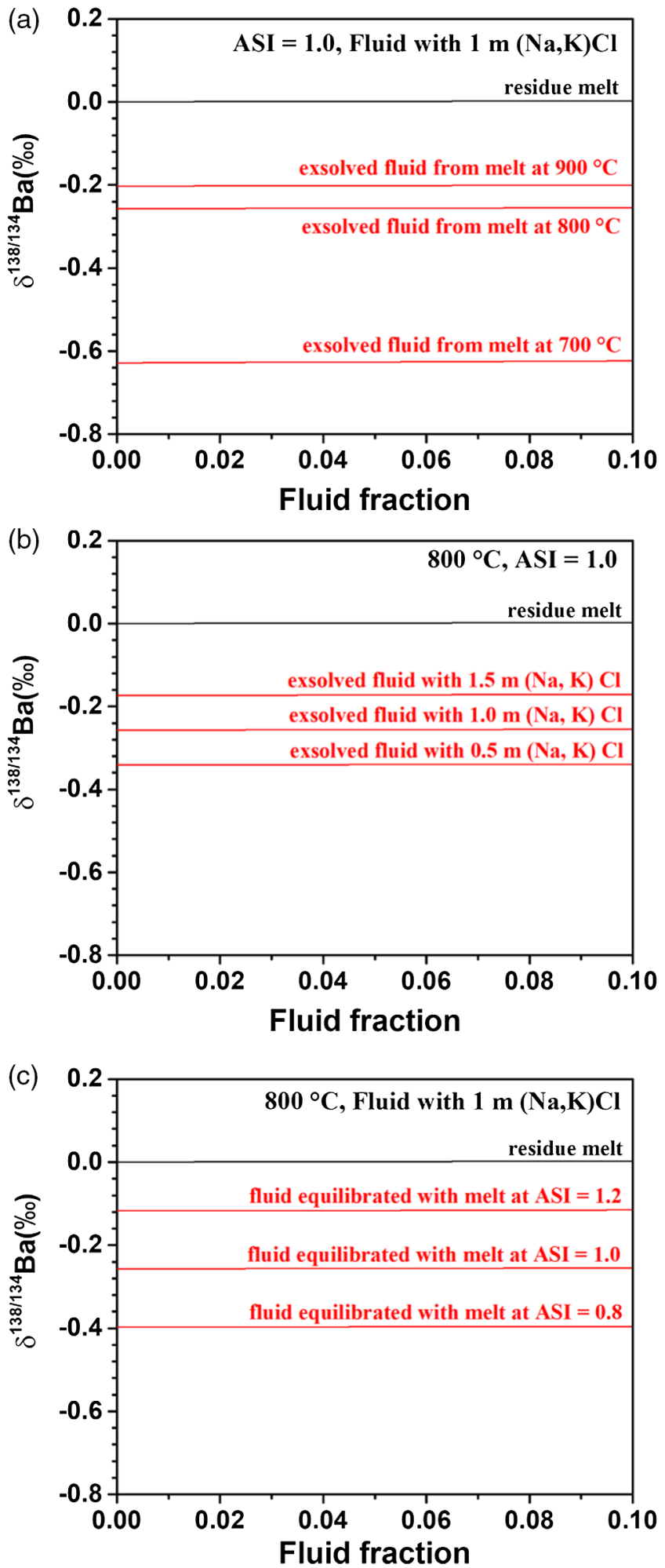

Figure 2 The modelled $\delta^{138 / 134} \mathrm{Ba}$ values of residue melt and exsolved fluid as a function of fluid fraction, using the Rayleigh fractionation model. The Ba isotopic composition of the initial fluid-saturated melt is set as $0 \%$, which is the average $\delta^{138 / 134} \mathrm{Ba}$ of the upper continental crust (Nan et al., 2018). Three factors affecting the $\mathrm{Ba}$ isotope fractionation between the melt and fluid are considered: (a) temperature, (b) salinity of the fluid, and (c) ASI of the melt. Based on Eq. S-1 in the Supplementary Information, the fluid phase only removes less than $2 \%$ of the total Ba from the hydrous magma system, even if the fluid exsolution fraction is as high as 0.1 . See text for the details. result is that $\delta^{138 / 134} \mathrm{Ba}_{\text {residual melt }}$ is similar to that of the initial melt (set as $0 \%$ in the model), regardless of the fraction of fluid exsolution, temperature, salinity of the fluid, and ASI of the melt. The reason for the nearly unchanged Ba isotopic composition of the residual melt after fluid segregation is that $\mathrm{Ba}$ is incompatible in aqueous fluids relative to silicate melts (Borchert et al., 2010; and this study), leading to limited fraction of Ba transferred from melts to fluids. For example, based on Eq. S-1 of the Supplementary Information, the fluid phase only removes less than $2 \%$ of the total Ba from the hydrous melt even if the fluid exsolution fraction is as high as 0.1 . On the contrary, the exsolved fluids display significantly lower $\delta^{138 / 134} \mathrm{Ba}$, down to $-0.63 \%$, than the residual melts (Fig. 2). The $\delta^{138 / 134} \mathrm{Ba}_{\text {exsolved fluid }}$ depends strongly on temperature (Fig. 2a), and also on salinity of the fluid and ASI of the melt (Fig. $2 \mathrm{~b}, \mathrm{c})$, i.e. $\delta^{138 / 134} \mathrm{Ba}_{\text {exsolved fluid }}$ increases with increasing temperature, the $(\mathrm{Na}, \mathrm{K}) \mathrm{Cl}$ concentration and ASI

\section{Implications}

Aqueous fluids could be derived from cooling of the hydrous crustal melts, when they rise up to the depth where the temperature decreases to the solidus. Our experimental results and models demonstrate that fluid exsolution from granitic melts cannot significantly affect the Ba isotopic composition of the residual melt (Fig. 2). Thus, our work supports the suggestion of Nan et al. (2018) that the light Ba isotopic compositions observed in some granites (Fig. S-1) probably result from fractional crystallisation of Ba-bearing minerals with heavy Ba isotopes rather than from fluid exsolution. More data from natural samples and experimental determination of the equilibrium $\mathrm{Ba}$ isotope fractionation factors between magmatic minerals and silicate melts are needed for further interpretation. In any event, the behaviour of $\mathrm{Ba}$ isotopes during fluid exsolution revealed in this study is essential for understanding the Ba isotopic signatures of granites.

The light Ba isotopic compositions of the aqueous fluids derived from magmas also have implications for tracing the process of extracting metal elements from magmas into fluids, which is an initial process (generally occurring at $\mathrm{T}>600{ }^{\circ} \mathrm{C}$ ) related to many kinds of magmatic-hydrothermal ore deposits. The hydrogen and oxygen isotopic data have been applied to discriminate the origin of hydrothermal fluids (e.g., Sheppard, 1986), as the magmatic $\mathrm{H}_{2} \mathrm{O}\left(\delta \mathrm{D}=-80 \sim-40 \%\right.$ o, $\delta^{18} \mathrm{O}=$ $\sim 5-10 \%$ o) has distinct $\mathrm{H}-\mathrm{O}$ isotopic compositions from the Global Meteoric Water Line (GMWL, $\delta \mathrm{D}=8 \delta^{18} \mathrm{O}+10$; Craig, 1961). However, since oxygen is a major component in both fluids and rocks, hydrothermal alteration of rocks may cause meteoric waters to have similar $\delta^{18} \mathrm{O}$ values to those of magmatic fluids. By contrast, Ba isotopes may serve as an effective tracer of magmatic fluids because hydrothermal fluids that exsolved from melts will be enriched in light $\mathrm{Ba}$ isotopes (Fig. 2), whereas meteoric waters with dissolved $\mathrm{Ba}$ are enriched in heavy $\mathrm{Ba}$ isotopes (e.g., $\delta^{138 / 134} \mathrm{Ba}$ ranging from $+0.17 \%$ o to $+0.46 \%$; Gou et al., 2020). For example, alkaline intrusions particularly have the capacity to form rare earth element and other metal deposits (e.g., Verplanck et al., 2014). According to Fig. 2c, the exsolved fluids from the alkaline intrusion systems (e.g., ASI =0.8) are expected to display significantly low $\delta^{138 / 134} \mathrm{Ba}$ (Fig. 3). In addition, pegmatites reacted with such exsolved fluids and volatiles with the potential for rare earth element mineralisation may also be characterised by light Ba isotopic compositions (Fig. 3). Therefore, Ba isotopes may be a new monitor for hydrothermal activities associated with metal mineralisation at shallow crustal levels. Such hypotheses can be tested by further measurements 


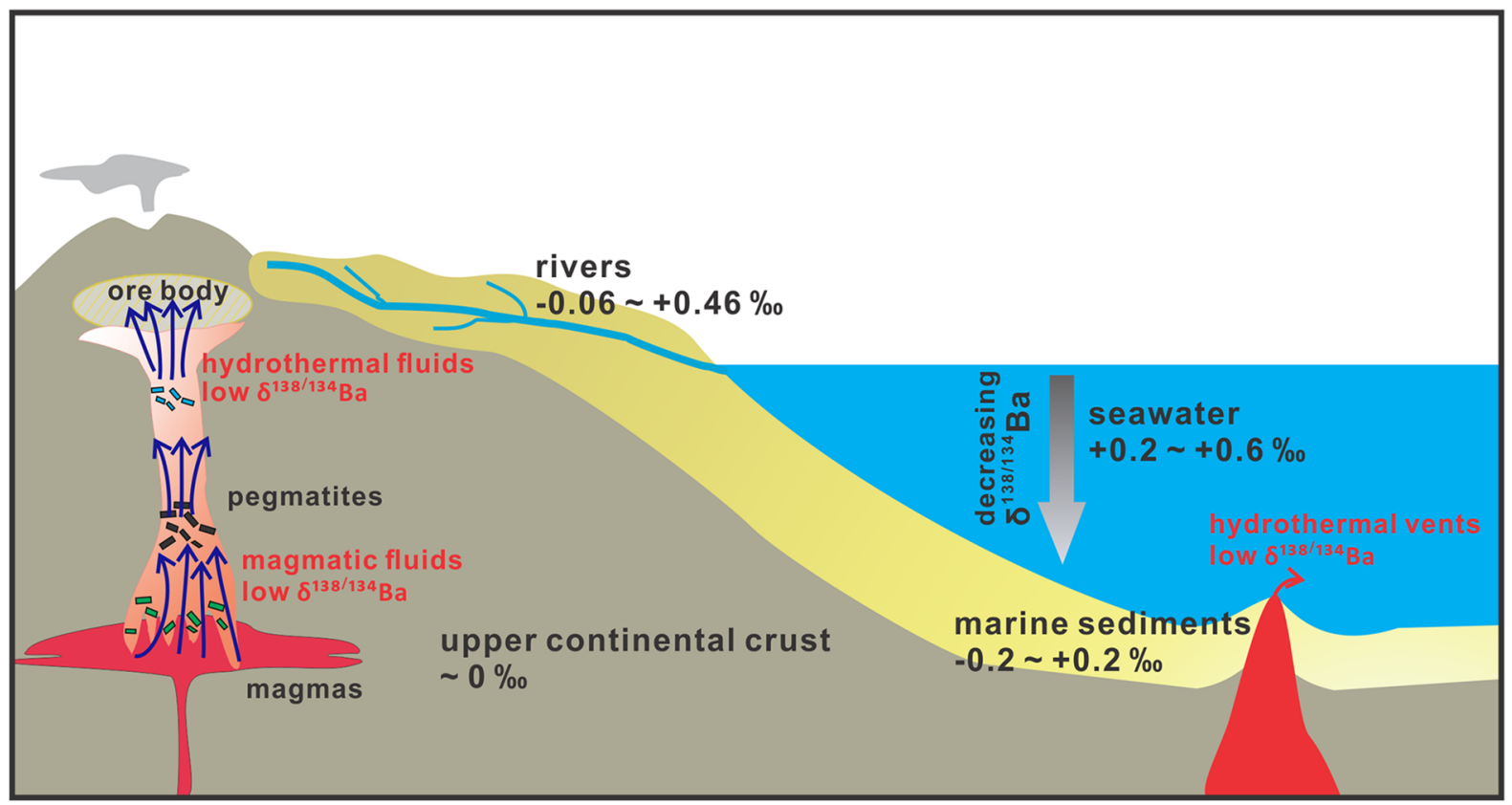

Figure 3 A schematic diagram illustrating the global $\delta^{138 / 134} \mathrm{Ba}$ isotopic characteristics of the upper continental crust, marine sediments, seawater and rivers as well as the relevant hydrothermal fluids and vents. The magmatic fluids, hydrothermal fluids and vents are expected to have low $\delta^{138 / 134} \mathrm{Ba}$ according to the negative $\Delta^{138 / 134} \mathrm{Ba}_{\text {FLUID-MELT }}$ values (from $-0.62 \%$ to $-0.14 \%$ ) obtained in this study. Data sources: Horner et al. (2015); Cao et al. (2016); Bates et al. (2017); Hsieh and Henderson (2017); Bridgestock et al. (2018, 2019); Nan et al. (2018); Nielsen et al. (2018); Crockford et al. (2019); Gou et al. (2020).

of the Ba isotopic compositions of pegmatite and hydrothermal deposit samples.

Supposing that basaltic melt has a similar structure to granitic melt, the exsolved fluids from seafloor volcanoes are also expected to have low $\delta^{138 / 134} \mathrm{Ba}(<0 \%)$, which will contribute to the hydrosphere (Fig. 3). The vertical ocean profiles have heterogeneous $\mathrm{Ba}$ isotopic compositions with the deep ocean being enriched in light $\mathrm{Ba}$ isotopes $(\sim+0.2 \%)$ relative to the surface ocean $(\sim+0.6 \%$; Fig. 3$)$. The light Ba isotopic compositions of the deep ocean have been suggested to result from dissolution of isotopically light barite during its sinking (e.g., Horner et al., 2015; Bates et al., 2017; Hsieh and Henderson, 2017; Bridgestock et al., 2018). Our results imply that, besides the effect of barite, fluid derived from the seafloor hydrothermal system may be another important source of isotopically light Ba to the deep ocean (Fig. 3), which should be taken into account in future studies on the global oceanic budget of Ba isotopes (the relevant Ba fluxes and isotopic compositions are shown in Fig. S-5). Collectively, our experimental results and models suggest that Ba isotopes could be a novel tracer for hydrothermal fluids in the shallow crust and at the seafloor, on the premise that more Ba isotopic data of granites, felsic intrusion-related hydrothermal deposits and seafloor hydrothermal vents will be accumulated.

\section{Acknowledgements}

We are grateful to Hui-Min Yu, Ying-Zeng Gong and Lan-Lan Tian for discussions. Heye Freymuth and an anonymous reviewer, as well as Editor Helen Williams for reviewing and improving the manuscript are thanked. This work is financially supported by the National Natural Science Foundation of China (42073004, 41803003), and the Open Research Fund of the State Key Laboratory of Ore Deposit Geochemistry of China (201805).

Editor: Helen Williams

\section{Additional Information}

Supplementary Information accompanies this letter at https:// www.geochemicalperspectivesletters.org/article2036.

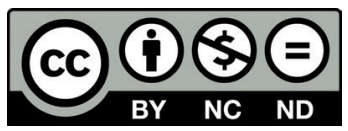

(C) 2020 The Authors. This work is distributed under the Creative Commons Attribution NonCommercial No-Derivatives 4.0 License, which permits unrestricted distribution provided the original author and source are credited. The material may not be adapted (remixed, transformed or built upon) or used for commercial purposes without written permission from the author. Additional information is available at http://www. geochemicalperspectivesletters.org/copyright-and-permissions.

Cite this letter as: Guo, H., Li, W.-Y., Nan, X., Huang, F. (2020) Experimental evidence for light $\mathrm{Ba}$ isotopes favouring aqueous fluids over silicate melts. Geochem. Persp. Let. 16, 6-11.

\section{References}

Bates, S.L., Hendry, K.R., Pryer, H.V., Kinsley, C.W., Pyle, K.M., Woodward, E.M.S., Horner, T.J. (2017) Barium isotopes reveal role of ocean circulation on barium cycling in the Atlantic. Geochimica et Cosmochimica Acta 204, 286-299.

Borchert, M., WilKe, M., SCHMidt, C., CAuZID, J., Tucoulou, R. (2010) Partitioning of $\mathrm{Ba}, \mathrm{La}, \mathrm{Yb}$ and $\mathrm{Y}$ between haplogranitic melts and aqueous solutions: An experimental study. Chemical Geology 276, 225-240.

Bridgestock, L., Hsieh, Y.-T., Porcelli, D., Homoky, W.B., Bryan, A., Henderson, G.M. (2018) Controls on the barium isotope compositions of marine sediments. Earth and Planetary Science Letters 481, 101-110.

Bridgestock, L., Hsieh, Y.-T., Porcelli, D., Henderson, G.M. (2019) Increased export production during recovery from the Paleocene-Eocene thermal maximum constrained by sedimentary Ba isotopes. Earth and Planetary Science Letters 510, 53-63.

CaO, Z., Siebert, C., Hathorne, E.C., Dai, M., Frank, M. (2016) Constraining the oceanic barium cycle with stable barium isotopes. Earth and Planetary Science Letters 434, 1-9. 
CRAIG, H. (1961) Isotopic variations in meteoric waters. Science 133, 1702-1703.

Crockford, P.W., Wing, B.A., Paytan A., Hodgskiss, M.S.W., Mayfield, K.K. Hayles, J.A., Middleton, J.E., Ahm, A.-S.C., Johnston, D.T., Caxito, F., Uhlein, G., Halverson, G.P., Eickmann, B., Torres, M., Horner, T.J. (2019) Barium-isotopic constraints on the origin of post-Marinoan barites. Earth and Planetary Science Letters 519, 234-244.

Eugster, O., Tera, F., WasserburG, G.J. (1969) Isotopic analyses of barium in meteorites and in terrestrial samples. Journal of Geophysical Research 74, 3897-3908.

Gou, L.-F., Jin, Z., Galy, A., Gong, Y.-Z., NAN, X.-Y., Jin, C., Wang, X.-D., Bouchez, J., CAI, H.-M., Chen, J.-B., Yu, H.-M., Huang, F. (2020) Seasonal riverine barium isotopic variation in the middle Yellow River: Sources and fractionation. Earth and Planetary Science Letters 531, 115990.

Guo, H., XIA, Y., BaI, R., Zhang, X., Huang, F. (2020) Experiments on Cu isotope fractionation between chlorine-bearing fluid and silicate magma: implications for fluid exsolution and porphyry $\mathrm{Cu}$ deposits. National Science Review 7, 1319-1330.

HeDEnquist, J.W., LowensteRn, J.B. (1994) The role of magmas in the formation of hydrothermal ore deposits. Nature 370, 519.

Horner, T.J., Kinsley, C.W., Nielsen, S.G. (2015) Barium-isotopic fractionation in seawater mediated by barite cycling and oceanic circulation. Earth and Planetary Science Letters 430, 511-522.

HsieH, Y.-T., Henderson, G.M. (2017) Barium stable isotopes in the global ocean Tracer of Ba inputs and utilization. Earth and Planetary Science Letters 473 269-278.

MANER, J.L., LONDON, D. (2018) Fractionation of the isotopes of boron between granitic melt and aqueous solution at $700{ }^{\circ} \mathrm{C}$ and $800{ }^{\circ} \mathrm{C}(200 \mathrm{MPa})$. Chemical Geology 489, 16-27.

Nan, X.-Y., YU, H.-M., Rudnick, R.L., Gaschnig, R.M., XU, J., Li, W.-Y., Zhang, Q. JIN, Z.-D., LI, X.-H., HuANG, F. (2018) Barium isotopic composition of the upper continental crust. Geochimica et Cosmochimica Acta 233, 33-49.

Nielsen, S.G., Horner, T.J., Pryer, H.V., Blusztajn, J., Shu, Y., Kurz, M.D. Le Roux, V. (2018) Barium isotope evidence for pervasive sediment recycling in the upper mantle. Science Advances 4, eaas8675.

RUDNICK, R., GAO, S. (2003) Composition of the continental crust. In: Holland, H.D., Turekian, K.K. (Eds.) Treatise on Geochemistry, Volume 3 The Crust, Pergamon, Oxford, 1-64.

SHEPPARD, S.M.F. (1986) Characterization and isotopic variations in natural waters. Reviews in Mineralogy and Geochemistry 16, 165-183.

Sun, S.-S., McDonough, W. (1989) Chemical and isotopic systematics of oceanic basalts: implications for mantle composition and processes. Geological Society, London, Special Publications 42, 313-345.

TIVEY, M.K. (2007) Generation of seafloor hydrothermal vent fluids and associated mineral deposits. Oceanography 20, 50-65.

Telus, M., Dauphas, N., Moynier, F., Tissot, F.L.H., Teng, F.-Z, Nabelek, P. Craddock, P.R., Groat, L.A. (2012) Iron, zinc, magnesium and uranium isotopic fractionation during continental crust differentiation: The tale from migmatites, granitoids, and pegmatites. Geochimica et Cosmochimica Acto 97, 247-265.

Verplanck, P.L., Van Gosen, B.S., Seal, R.R., McCafferty, A.E. (2014) A deposit model for carbonatite and peralkaline intrusion-related rare earth element deposits. U.S. Geological Survey Scientific Investigations Report, 2010-5070-J.

WORKMAN, R.K., HART, S.R. (2005) Major and trace element composition of the depleted MORB mantle (DMM). Earth and Planetary Science Letters 231, 53-72. 